Check for updates

The BMJ

Cite this as: BMJ 2021;373:n1361 http://dx.doi.org/10.1136/bmj.n1361 Published: 25 May 2021

\title{
Covid-19: Local councils initiate surge vaccination to tackle B.1.617.2 variant
}

\section{Gareth lacobucci}

Local public health teams in areas with high case numbers of the B.1.617.2 variant first detected in India are boosting efforts to vaccinate their populations and targeting younger adults to try to limit the spread of infection.

The actions come amid growing concerns about the rise in infections of B.1.617.2, with early data from Public Health England ${ }^{1}$ suggesting that one dose of both AstraZeneca and Pfizer vaccine is only $33 \%$ effective against the variant.

National guidance from the Joint Committee on Vaccination and Immunisation continues to advise vaccinating adults according to risk profile and age-with people aged 30 being offered the vaccine this week. But some local authorities have taken matters into their own hands and are offering any adult aged 18 or over a vaccination.

Bolton in Greater Manchester, which has the highest rate of the B.1.617.2 variant in the country, is among those to implement surge vaccination, and has been encouraging all adults to come forward for a vaccination. ${ }^{2}$ Surge vaccination means preferentially targeting younger and unvaccinated adults in areas with high prevalence or rapidly growing outbreaks of the B.1.617.2 variant. ${ }^{3}$

Nearby Blackburn and Darwen in Lancashire, which also has high prevalence of the variant, has sourced extra doses of Pfizer vaccine and commissioned a special vaccination bus to vaccinate anyone aged 18 and over, subject to eligibility. ${ }^{4}$

Manchester City Council leader Richard Leese ${ }^{5}$ has indicated that the city will also look to vaccinate younger people in response to the increase in cases in the region. "By getting to younger people, what we want to do is stop that transmission," he said.

Other affected areas, including Rochdale in Greater Manchester, ${ }^{6}$ Leicester, ${ }^{7}$ Hounslow in west London, ${ }^{8}$ Bedford, ${ }^{9}$ and North Tyneside ${ }^{10}$ have deployed a range of tactics for tackling rising cases of the variant, including surge vaccination, extra clinics, and bringing forward second doses.

Andrea Fallon, Rochdale's director of public health, said, "We are looking for reasons to vaccinate people, not reasons to turn people away. The more people who are vaccinated, the more we suppress the virus and protect each other."

A recent paper from SAGE's Scientific Pandemic Influenza Group on Modelling, Operational sub-group ${ }^{3}$ argued there is a "strong case" to carry out surge vaccinations for younger age groups in areas where the number of cases of the variant is high.
"While the success of a surge vaccination programme is not guaranteed, from a non-operational epidemiological perspective alone, it has a large potential upside with relatively small potential drawbacks with regard to transmission," the paper said.

Mike Gill, former regional director of public health for south-east England, said he understood why surge vaccination was being deployed in some areas, but said "opportunity costs" like the impact on vaccine supply and the availability of staff needed to be factored in.

He told The BMJ, "It's a difficult balancing act. If you are vaccinating other groups for the first time, then you wouldn't want to be denying people who need their second dose. The other drawback is the human resource cost. There aren't as many people as we need to deliver it, given we also need to tackle the huge backlog in non-covid care.”

\footnotetext{
lacobucci G. Covid-19: Single vaccine dose is 33\% effective against variant from India, data show. BMJ2021;373.

2 Covid-19: thousands of people "including some as young as 17" turn up for walk-in jabs in variant hotspot areas. https://news.sky.com/story/covid 19-thousands-of-people-including-some-as-young-as-17-turn-up-for-walkin-jabs-in-variant-hotspot-areas-12308808.

3 SPI-M-O. Consensus Statement on covid-19. May 2021. https://assets.publishing.service.gov.uk/government/uploads/system/uploads/attachment_data/file/986709/S1237_SPI-M-O_Consensus_Statement.pdf

4 NHS BwD CCG. 23 May 2021. https://twitter.com/BwDCCG/status/1396395176763985923?s=20.

5 Covid: Manchester council offers vaccines to over-18s. BBC News. 21 May 2021. www.bbc.com/news/uk-england-manchester-57205345.

6 Rochdale Borough Council. Huge response to extra vaccination clinics. 24 May 2021 www.rochdale.gov.uk/news/Pages/huge-response-to-extra vaccination-clinics.aspx.

7 Plans announced to speed up covid vaccinations in Leicester. 25 May 2021 www.leicestercityccg.nhs.uk/news/ccg-news/plans-announced-to-speedup-covid-vaccinations-in-leicester.

8 Surge testing and vaccinations in Hounslow. www.hounslow.gov.uk/surge.

9 BLMK CCG. Super Sunday is a soaring success. 24 May 2021. www.blmkccg.nhs.uk/super-sunday-is-a-soaring-success.

10 Mobile vaccination services and testing up and running this week in North Tyneside. https://my.northtyneside.gov.uk/news/28321/mobile-vaccinationservices-and-testing-and-running-week-north-tyneside.
}

This article is made freely available for use in accordance with BMJ's website terms and conditions for the duration of the covid-19 pandemic or until otherwise determined by BMJ. You may use, download and print the article for any lawful, non-commercial purpose (including text and data mining) provided that all copyright notices and trade marks are retained. 